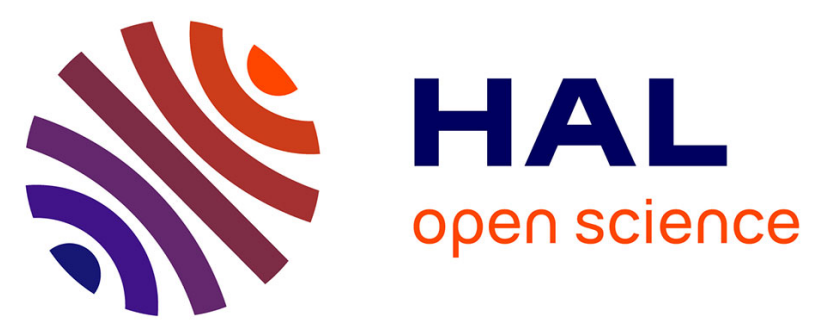

\title{
Excimer laser deposition of apatite at room temperature on titanium substrates
}

\author{
E. Antonov, V. Bagratashvili, E. Sobol, R. Smith, S. Howdle
}

\section{To cite this version:}

E. Antonov, V. Bagratashvili, E. Sobol, R. Smith, S. Howdle. Excimer laser deposition of apatite at room temperature on titanium substrates. Journal de Physique IV Proceedings, 1994, 04 (C4), pp.C4-183-C4-186. 10.1051/jp4:1994441 . jpa-00252704

\section{HAL Id: jpa-00252704 https://hal.science/jpa-00252704}

Submitted on 1 Jan 1994

HAL is a multi-disciplinary open access archive for the deposit and dissemination of scientific research documents, whether they are published or not. The documents may come from teaching and research institutions in France or abroad, or from public or private research centers.
L'archive ouverte pluridisciplinaire HAL, est destinée au dépôt et à la diffusion de documents scientifiques de niveau recherche, publiés ou non, émanant des établissements d'enseignement et de recherche français ou étrangers, des laboratoires publics ou privés. 


\title{
Excimer laser deposition of apatite at room temperature on titanium substrates
}

\author{
E.N. ANTONOV, V.N. BAGRATASHVILI, E.N. SOBOL, R. SMITH* and S.M. HOWDLE**
}

Sci. Res. Center for Technol. Lasers, Troitsk 142092, Russia

${ }^{*}$ IRC in Biomedical Materials, E14NS, London, U.K.

${ }^{* *}$ Chem, Departm. Nottingham Univ., NG7 2RD, Nottingham, U.K.

\begin{abstract}
Highly adhesive apatite films were deposited by pulse laser sputtering of apatite target on $T i$ substrates at room temperature. The model of laser anlation/deposition of multicomponent solids was discussed to explain the observed differences in the properties of films obtained from apatite mineral, sintered hydrohyapetite, and bone tissue tarats.
\end{abstract}

\section{INTRODUCTION}

Hydroxyapatite (HA) is the mineral base of bone tissue and is used as a biologically compatible coating for medical and dental implants [1]. Plasena spraying is commonly used for HA deposition, but recently laser assisted film deposition techniques have been used successfully [2-4]. Crystalline films of HA have been obtained by manipulation of the laser fluence and the atmospheric corditions and use of high substrate temperatures, $>400^{\circ} \mathrm{C}$ [2]. In our experiments, nacural apatite [NA] samples were successfully used for fila deposition of high quality coatings on ti substrates at room temerature.

EXPERIMENTAL.

Three types of samples $\mathrm{HA}$, NA and bone tissue were used as targets for ajatite film depasition by KrF-excimer laser, $\lambda=248$ nm (EMG-203, Lambda physik). In our experiments the focused uv laser bean was scanned periadically across the target in order to avoid the formation of deep craters in the target. The laser pulse repetition rate was $5 \mathrm{~Hz}$, pulse energy up to $300 \mathrm{~mJ}$ (controlled by attenuator), and laser pulse fluence on the target was $0.7-11 \mathrm{~J} / \mathrm{cm}^{2}$. The target to substrate distances were $3.5 \mathrm{~cm}$ and a Ti foil target $(0.05 \mathrm{~mm}$ thickness) was used as substrate for apatite deposition. The film thickness was varied from 0.1 to -2 fin and the deposition rate was in the range 0.02 - 5 A/pulse. Residual air pressure in the vacuum cell was maintained at $3 \cdot 10^{-2}$ Torr.

The deposited apatite films were examined by SEM, FT-IR and-Raman spectroscopy. The film adhesion was jetermined by a scratch test; a unique cuantitative method for very thin films [5]. The scratching uas made by a corundum point with a 57 fin radius. The adhesive force was determined by 
the maximum vertical load which could be applied to the point, without stripping the film from the substrate [5].

\section{RESULTS}

Most of our investigations were made with titanium substrates; an important implant material. The films deposited from HA and NA samples were mirror-like and scanning electron micrographs showed snooth surfaces with round shaped particles of 1-10 $\mathrm{m}$ in size. Both the quantity and the size of particles controlled by increasing the laser fluence. The films deposited from bone tissue were much more spongy and round shaped particles appeared only at the fluences more than $.5 \mathrm{~J} / \mathrm{cm}^{2}$.

The adhesion of films on Ti substrates vs fluence is shown in fig.1. With a substrate temperature of $400^{\circ} \mathrm{C}$, both $H A$ and NA films have excellent adhesion with a maximum fluence near $2-4 \mathrm{~J} / \mathrm{cm}^{2}$. This is in accordance with the results of [2]. Conversely, the adhesion of films obtained at room temperature from $H A$ and bone was quite low. The most striking results were obtained with films prepared from NA at room temperature. In the fiuence range 2-4 J/cm ${ }^{2}$ those films have practically the same adhesion level as the films deposited at $400^{\circ} \mathrm{C}$.

The films were investigated by FT-IR spectroscopy. The vibration bands of the phosphate ions $\left(\mathrm{P0}_{4}^{3-}\right)$ of $\mathrm{HA}$ appear in the range $550-610$ cm and 1000-1100 $\mathrm{cm}^{-1}$ respectively [6]. The film spectra, obtained from NA, and the initial spectra of $H A$ and $N A$ are given in fig. 2 .

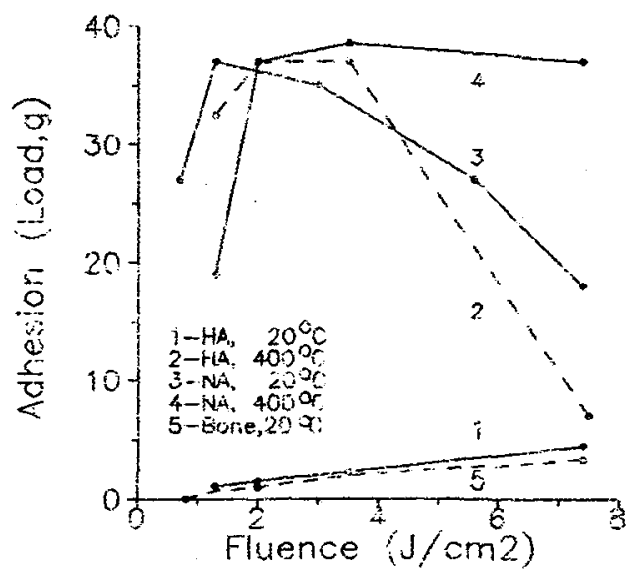

Fig.1. The adhesion of fims obtrined fiom different iargets

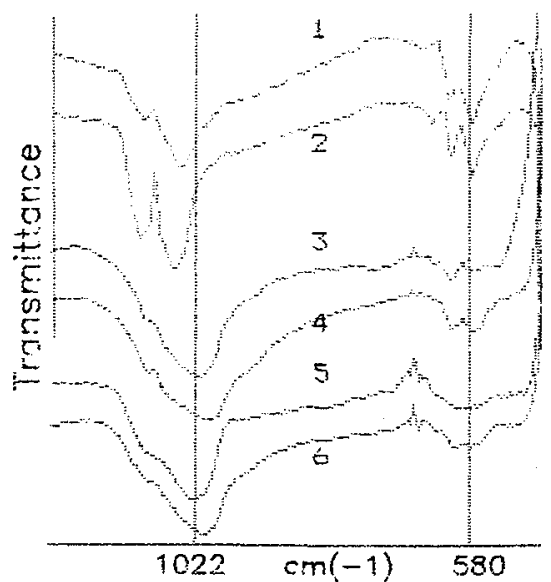

Fiq.2. FT-IR spectra of $\mathrm{NA}-(1)$. $\mathrm{HA}-(2)$ and $\mathrm{NA}$ films: at $20 \mathrm{C}$, $2,1 / \operatorname{com}^{2}-\{3), 7, j / 0 m 2-(4) ; 0 t$ $400^{\circ} \mathrm{C}, 2 \mathrm{j} / \mathrm{sm}^{2}-(5), 7.3 \mathrm{j} / \mathrm{cm}^{2}-(5)$ 
Note the close similarities between the spectra of HA and NA. The FTRaman spectra of HA and Na films aro also almost identical at the same laser fluences and sibstrate temperatures. As the laser fluence is increased, the maximum of the main absorption peak in the FT-IR soectra shifts to lower frequencies. A particularly striking feature of the spectra cbtained at $400^{\circ} \mathrm{C}$ is the strong feature near $1110 \mathrm{~cm}^{-1}$.

These data show. that there is no direst correlation batween the spectral features and the adhesion properties. Houever for different targets and substrate cemperatures, we have shown that the mechanical properties of the films may be characterized by spectral methods without destruction of the materials.

\section{DTSCUS5ION}

The film adhesion at a quen substrate temperature depends on the size (d) and velocity (y) of particles enitied from the target. The $u$ and $y$ values are determined firstly by ablation and secondly by coilisional processes and ather parameters. Laser irradiation of the targets fesults in enission of icns, etoms and nicro particles of varicus sizes. These species reaco the substrate with velccities vilo $-10^{6}$ cmisec. [7], ard forma dense tilm. The particies with $d 10$ jum have $\times 10^{\circ}$ cisisec. hence producing isore epongy fins with poor adtesion.

Ue have developed models for aratysis of laser induced decomposition of

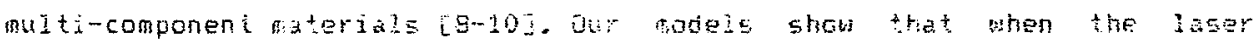
strikes the target, there is a fiuence regios in which the temperature front of the chenican reaction vales with timt. Hence the gas pressure caused oy the chemical and physcal ptoceses at ablation, also fluctuatos.

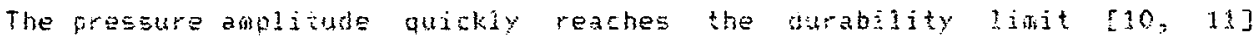

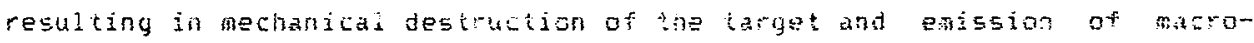
particles. The particle sizes are deterained by the deconpastion on the scale of reaction front distance and bo not exceri the value liod where W-absorption ceetficient.

For HA and NA, vaporization is the wajo prosess of material ablation. However, vaporization may be accompanied by molecular deconposition. This process is a high tenperature and mist give the particles with the traces of meiting. For tone ablation the decomposition of collagen st $350-400{ }^{\circ} \mathrm{C}$ leads to destruction terore vaporization and the particles froduced must show an irreguiar form.

Theoretical analysis [10] show that there is an optinal fluence region

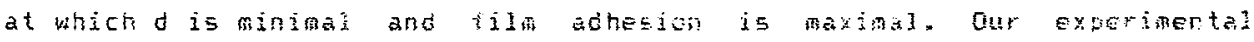
resuits are in agreement with this moded. For gi guatitative ramarisan, a more precise definition of optical, thermal ard mechanical paraneters is 
needed. The different adhesion properties of His ard NA films prepared at room temperatures may be caused by the differences in absorption: coefficients or in mechanical properties of the taroet materlals. At the High substrate temueratures, the erystallisation processes become more important [2]. Note, we estimate that the increase of substrate temporature due to the kineiic energy of evaporated particles was is less than $10 k$.

To ameliorate the film quality it is possible to introduce highly absorbing impurities into the initial meterials. Thus increasing the erergy absorbed by the targets or, one my use a laser wavelength zt which the absorption of the target material itself is higher.

\section{SUAMARY}

We have developed laser sputtering testriques which aliow deposition of bigh quality apatite films on to substrates at room temperature; the first time such low temperatures have been tred successfully. We bave deposited films on to titanium substrates and these show excellent adhosion characteristics. A theoretical model of 1 aser ablation of nuli-component solids was discussed to explain the differences in the experimental results abtained uith difierent targets-4A, NA and bone tissue. We hope that these results will be userul to develop the practical tochology of apatite film denosition for different medical ard bental iaplants.

\section{REFERENCES}

1. L.L.Henct, J.Wilson, MRS Bu11, 62, segt. 1991

2. G.Sardin, F.Ssnchez, M.Varela, J.L.Morenza, E-MRS Fall Meeting, D-1.3, Strasbourg, Nov. 3-6, 1992.

3. C.M.Cotell, Appl. Surface Sci..1993, v.69, p.140

4. E.N.Antonov, U.N Bagratashviji, Y.Ya.Panchenko.A.F, Svirijov, E.N.Sobol, Pisma v J.Technich. Fiziki (Rus), 1993, v.19, p.92

5. P.Benjamin, C.beaver, Proc. Roy. Soc. 1960, y.254A, D.163

6. M.A.walters, Y.C.Leung, N.C.Blumenthal, R.Z.be Geros, K. A.Konske;, 3. Inorg. Biochem. 1990, v.39, 0.193

7. R.K.5ingh, 0.W.riolland, J.Narayan, J. Appl. Phys., 1990, v.68, p.23J

8. E.N.Sobol, J. Technich. Firiki (Rus), 1982, V.52, p.1697

9. E.N.Sobol, Pisma v J.Technich. Fiziki (Rus), 1989, v.15, p.80

10. E.N.Sobol, N.G.Petrovskaya, Supercond. Sci. Technol., 1993, V.6 p.67

11. P.E.Dyet, S.Farrar, Appl. Phys. Lett.,1992. v.60, 0.1890 